\title{
Dynamite Regulations. The Explosives Industry, Regulatory Capture and the Swedish Government 1858-1948
}

\author{
Josefin Sabo $^{1} \cdot$ Lena Andersson-Skog ${ }^{1}$
}

Published online: 2 May 2017

C) The Author(s) 2017. This article is an open access publication

\begin{abstract}
In this article, we argue that the regulation of the explosives industry in Sweden between 1858 and 1948 can give a slightly different perspective on regulatory capture. In this case it was the upstart company, the Nobel Dynamite Company, and not the established explosives companies that in negotiation with the regulator succeeded in establishing new national regulations. Through three different cases we show that the method behind this successful capture was indirect and direct with a common trait of risk minimizing for the public that developed in cooperation with the regulator.
\end{abstract}

Keywords Sweden · Dynamite $\cdot$ Regulatory capture $\cdot$ Industrialization · Governmentmarket relations

JEL Classification $\mathrm{N} 10 \cdot \mathrm{L} 50$

\section{Introduction}

Many scholars when studying institutional change and regulatory processes have identified regulatory capture as a major problem as it distorts market conditions and is the result of a bargaining process where certain interests are prioritized over others (Stigler 1971; Peltzman 1976; Becker 1983; Hady 2006). In the regulatory capture literature, the capturer is often pictured as the established, mature party, a company or branch already dominating an industry. A classic example is George

Josefin Sabo

josefin.sabo@umu.se

1 Unit of Economic History, Department of Geography and Economic History, Umeå University,

Umeå, Sweden 
Stigler's well-known case of competition on the transport market during the interwar years in the U.S. The railroad industry responded to the increasing competition from trucks by influencing authorities to introduce government regulation that restricted the allowed transport weight of the trucks, thus limiting competition in advantage of railroads. (Stigler 1971). According to Stigler, there are several ways of achieving regulatory capture, for example, by direct methods, such as discriminating pricing policies and vertical integration. Indirect methods, such as establishing of long-term personal relationships between corporate managers and technicians from the industry and officials with the regulatory authority, may also be used. Here, a close collaboration may also involve certain mutual advantages, such as building trust and future loyalty, cooperation with and obedience to the law. Regulatory capture is, for obvious reasons, often considered to be an obvious risk of distorted conditions on the market. Posner (1974), Peltzman (1976), and Becker (1983) also argue that when the line between governmental and market interests is blurred, the regulatory process opens up to the influence of other pressure groups outside the industry. Recent literature has shown that regulatory capture can be found in various areas like transportation and telecommunications, energy and environmental policy, farming and financial services (Hady 2006; Smyth and Söderberg 2010). Regulatory capture must also be considered in light of other regulatory concepts, where there is a common distinction between self-regulation, co-regulation and government regulation. Government regulation is a process in the political arena, without access to private interests, whereas self-regulation means that the company or economic actor makes decisions that are not necessarily profit maximizing in the short run, but result in other kinds of benefits. Co-regulation indicates a government that controls rule-making, but delegates the implementation of regulatory decisions to the market (Latzer et al. 2003; Funke 2015). Co-regulation characterized the regulatory process in Sweden during the 1960s and 1970s, when the Rönnskär smelter, the world's largest producer of arsenic emissions practically abolished them as a result of the active involvement, initiatives and the leading role played by the company in the regulatory process and the establishment of a new legislation. This was a process of regulatory capture and co-regulation that benefited all parties (Bergquist 2007).

In this article, we argue that the regulation of the explosives industry in Sweden between 1858 and 1948 can put a slightly different perspective on regulatory capture. First, in this case it was the upstart company, the Nobel Dynamite Company, not the established explosives companies that, in negotiations with the regulator, succeeded in establishing new national regulation. Second, the method behind the successful capture combined indirect and direct methods with a common risk-minimizing trait for the public and it developed in cooperation with the regulator.

This paper briefly describes the industrializing government, technological development and regulation in the nineteenth century Sweden. A short description is given regarding the traditional explosives industry and its regulation from the black powder era to the modern dynamite industry. Three decision-making processes are discussed as examples of regulatory capture in relation to the Nobel company. Regulatory capture and self-regulation are also discussed. 


\section{Industrializing Government, Technological Development and Regulation in Sweden}

From the late nineteenth century, industrialization in Sweden was in full swing, and annual growth was among the highest in the world. Besides the obvious importance of the international demand for Swedish natural resources, two other explanations are often emphasized as key factors behind the rapid development of the Swedish industry.

First were the amazing achievements of a handful of Swedish inventors and entrepreneurs in building internationally successful corporations and promoting their inventions in the international market (Andersson-Skog and Magnusson 2014). Second, there is a strong, intertwined, long-lasting techno-economical and political collaboration in technological research that emerged between Swedish authorities and private key industries (for instance, the State Railroads and Allmänna Svenska Elektriska Aktiebolaget (now ABB: ASEA/BrownBoweri), the State Telegraph and L M Ericsson (now Ericsson)) usually called development pairs (Fridlund 1999). In a development pair, the mutual benefits for the company (in terms of technological development and access to capital and markets) and for the government (access to technological expertise) are seen as the dominating raison d'être for a joint technological research and development strategy. Third, early on the Swedish government became an active regulator of industries, as well as an active producer of goods and services. Sometimes the activities were organized in government agencies, for instance the State Railroad Board from 1888. Sometimes the activities were joint ventures together with private business interests, for example Loussavaara Kiirunavaara Aktiebolag (LKAB), the major Swedish iron-ore mine from 1907. The active industrializing government fostered long-term government-market relations that were market-oriented and fostered a cooperative technological development. This was not, however, the relationship that evolved between the government and the modern explosives industry, which was founded by Alfred Nobel, perhaps the most famous Swedish inventor of the nineteenth century.

\section{The Traditional Explosives Industry, new Technology and Changing Markets: A Missed Opportunity}

From the Middle Ages, Sweden had a comprehensive mining industry that exported large quantities of pig and bar iron, silver and copper. A prerequisite for this was access to black powder. In 1641 the first big powder mill, Akers Krutbruk, was founded. With the expanding industrialization in Western Europe from the eighteenth century on, the demand for iron increased. A large number of powder mills were established from the 1700s onwards in the major iron works region. From the sixteenth century, black powder production in Sweden was due to the Crown's declared privilege. Black powder trade was a Crown monopoly. From 1775 the regional authorities, i.e. the Royal Commissioner, were given great authorization to allow the foundation of powder mills and powder production in his county. A close relationship between local producers and regional authorities evolved over time, and 
in some cases the authorities were active in prohibiting competition between different mining companies and powder producers (Andrén 1964). During the 1850s, however, the demand for explosives changed. Industrialization intensified, and new expanding markets occurred with the building of railways, ports and harbors, roads and canals. As the market grew, the need for control increased and black powder regulation was, therefore, introduced in 1858.

Alfred Nobel and his invention of blasting oil and dynamite laid the foundation for the world's first dynamite company, Nitroclycerin Aktiebolaget (The Nobel Company) established in Stockholm in 1864. All research and development was carried out in the laboratories of Nobel's international companies, and to some extent in the Nobel Company. Nobel left the Swedish company in 1865 , but continued to give improved patent rights for Sweden to his old company (Lundström 1974). The traditional powder industry made serious attempts to enter the nitroglycerin and dynamite market, by patent infringements and their own technical research and development attempts. Nora Gyttorp Krutbruk was especially successful and became a fierce competitor to the Nobel Company in many regions.

From this starting point, it was not evident that the startup company, the Nobel Company, would come out on top in the competitive market. But at the beginning of the 1900s, three companies held $97 \%$ of the explosives market in Sweden, the Nobel Company being by far the largest of them (Andrén 1964).

Why did the mature companies not succeed in keeping their positions? One explanation is the strong regional character of the established industry. The Nobel Company early on acted on a national market, not depending on the traditional regional agreements between mining and explosives industries. Ongoing technological research and new and improved patents the Nobel Company participated in, led to an increasing disparity in practical and technological know-how and scientific knowledge between the Nobel Company and the government. In older, established traditional industries, such as mining and iron production, the knowledge gap was much narrower, since the Swedish government relied on public servants with practical and judicial expertise. With the new explosives, nitroglycerin and dynamite, the government became dependent on the Nobel company to provide technical, practical and managerial expertise in building a new regulatory framework needed for the growing industry. Unlike the other actors, the Nobel Company communicated with the government to influence future legislation.

\section{Dynamite Regulations in the Making - The Nobel Company and Three Cases of Regulatory Capture}

We will analyze three decision-making processes as examples of direct and indirect regulatory capture. The first related to cases where a nitroglycerin ban was introduced in Sweden in 1868, the Nobel Company influenced the decision to impose prohibition. We also examine attempts by traditional regional industry interests to obstruct passage of the government bill for a national regulatory authority, the Inspectorate of Explosives, and the Explosive Act of 1897. Third, the long-term and close relationship between the Nobel Company and the explosives authority will be discussed to show how the company benefited through regulatory measures. 


\section{From "Harmless" Explosive Oil to a Ban on Liquid Nitroglycerin in 1868}

The production, transport, use and storage of blasting oil and dynamite were generally hazardous and, in all too many cases, lethal. In particular, the early industry was afflicted with accidents, threatening public safety as well as the health and safety of the workforce and customers. Hence, the prime incentive for technological research and development was to make the product safer so as to avoid legislative measures banning it.

Accidents related to the manufacturing and handling of nitroglycerine expanded, not unexpectedly, with the increasing production. As a result, trade with and transport of nitroglycerin was regulated in 1865 . Despite efforts to control the risks, the accident rate continued to increase. In 1866 a series of accidents occurred around the world and as a result, liquid nitroglycerin was prohibited in many countries.

In Sweden a prohibition on selling and transporting liquid nitroglycerin was introduced in 1868. The decision to introduce the ban was prompted by two accidents that occurred that year. Although the first accident happened in Belgium, it was the second accident that led to the greatest fear among the Swedish population, since it occurred at the Nobel Company's factory in Stockholm where 14 people were killed. The proposal for a nitroglycerin ban was initiated by the Stockholm County Administrative Board, which considered a prohibition necessary in order to reduce fear among city residents. Surprisingly enough, the Nobel Company was quick to agree. The company had previously emphasized that liquid nitroglycerin was a relatively safe explosive and had also managed to convince the government that such was the case, which made this change of opinion paradoxical. Only a few days later, they wrote to the government with a request for a general ban on all trade and use of liquid nitroglycerin.

The reason behind the changed opinion was that the Nobel Company was given a patent in Sweden for dynamite from 1867 to 1880 . In the proposal to the government, the company argued that they found it both desirable and justified that dangerous nitroglycerin was replaced by harmless dynamite. The company, therefore, urged the government to obstruct the trade and use of nitroglycerin by issuing heavy fines. The company's attitude had thus changed radically, and it was a strategic choice. A ban would not impose disadvantages for the company as long as the dynamite patent was in force, since the competitors' production was limited to the liquid nitroglycerin during that time.

The strategy of the company was to convince the government that the risks associated with the liquid nitroglycerin were so high that a ban should be issued, a ban that would almost exclude competitors from the market in two ways. First, liquid nitroglycerin would be prohibited, and second, the Nobel Company would have a de facto monopoly on the new dynamite market. The company might, however, have desired a ban for reasons other than excluding the competitors from the market, namely for the common good. The dynamite was actually safer to use and the company was keen to protect those who in various ways handled the dynamite and cared about the safety of their customers. With the dynamite patent under its belt, the company had a monopoly situation and benefited the common good.

Only a few weeks after the company's proposal, the government issued the nitroglycerin ban. It is thus clear that the company succeeded in capturing the government and moreover restricting competition in the market. 


\section{Fighting for Traditional Regulation: Regional Interest and the National Regulator 1894-1897}

The nitroglycerin ban of 1868 was soon replaced in 1869 with a new explosives act for manufacturing and sale of nitroglycerin, dynamite and other explosives. During the 1870 s, there was rapid technological development and many alternative explosives quite similar to the Nobel dynamite were patented. The number of powder mills experimenting with dynamite increased, as did the number of new companies. In 1873, the government appointed an explosives inspector responsible for monitoring production of dynamite and explosives all over Sweden. The first inspector, Professor Cronquist, came in contact with the Nobel Company in 1865 when he conducted an investigation about nitroglycerin explosives. Since he did not have any knowledge about nitroglycerin, he received large parts of his technical know-how within the company. In reality, the inspections were irregular and occurred due to requests from the public, regional authorities or competitors to a certain producer.

In 1897, a new explosive act was introduced that replaced previous regulations. The new regulation, among other things, stated that the explosives inspector would be given greater influence over the introduction of a regulatory agency, the Inspectorate of Explosives. This was a definite break with earlier, pre-industrial institutions, since it meant that the new national agency was given supremacy over the regional authorities such as the County Administrative Boards. The instigation of the Explosives Inspectorate in 1897 was a result of a legislative process that involved many stakeholders and different interests. On one side was the government, the Inspectorate and the Nobel Company, and on the other side were a number of dynamite companies, powder mills and other explosive producers.

The proposal for the new explosives act had been prepared by a committee appointed by the government in 1892. Among the experts appointed to prepare the proposal was Professor Cronquist. Discontent from the industry was widespread and in 1894 a protest meeting was held, where around 40 actors expressed dissatisfaction with the proposed act. The meeting occurred on the initiative of the managing director, A.E. Salwén from $A B$ Express-Dynamit, and the managing director, A. Lundeberg at Gyttorps Sprängämnesaktiebolag, and took place in Örebro, a city close to the traditional mining and iron production region. Professor Cronquist had been appointed to defend the Commissioner's proposal.

Protests were mainly made against the fact that the explosives inspector would be given greater influence at the expense of the County Administrative Board. For example, with the new act, the right to pursue factory-scale production of explosives was no longer a matter the regional board could decide on. Just like before, applications were sent to the Royal Commissioner in the county where the production was to be pursued, but the Commissioner had to hear the inspector's opinion before the application could be approved. Discretionary power was given to the Inspectorate.

This issue was heavily opposed. The representative from AB Express-Dynamit argued that the regulation intended to make the explosives inspector an authority above the Royal Commissioner was unthinkable. Cronquist responded that the paragraph referred to the establishment of a factory producing a new explosive of unknown composition and that the inspector should be given the opportunity to evaluate the explosive in relation to public safety and decide whether the explosive was too 
dangerous to produce. The discussion led to a resolution that the County Administrative Board henceforth should also implement supervision over the order at the explosives factories without having to depend on the inspectors' provisions. On an initiative from the representative of Gyttorps Sprängämnes $A B$, a committee appointed at the meeting was commissioned to prepare an amendment to be personally handed over to the government.

Business at large was not satisfied with the introduction of an authority that formalized contact between them and the national decision-making authority. Since the Nobel Company did not raise any objections against the proposal to introduce a government authority, it is likely that the company shared the government's view since in practice it would not be as concerning for them as for other companies.

\section{Raising Barriers to Entry: Co-Regulation, Technology and Markets}

Since the Nobel Company emerged as the largest and most important explosives company from the beginning of the twentieth century, there is no doubt that close cooperation evolved between the Nobel Company and the Inspectorate. The Inspectorate acquired considerable technical knowledge and specialist expertise needed from employees in the Nobel Company when the authority had to evaluate new products and inventions that hit the market. In most cases the assessment of risks and the required safety measures made it vital. This more professional or technical relationship was underpinned by more personal relations between the Inspectorate and the company management.

Gottfried von Feiltizen, the explosives inspector between 1910 and 1938, had a long and close relationship with the Nobel Company. After graduating as a chemist in 1895, he worked as an assistant to Alfred Nobel, and in 1905 he became the technical director at the Nobel Company's dynamite factory (Andrén 1964).

There are several examples of an interaction between the explosives inspector and the Nobel Company, and the close relationship probably contributed to the favorable situation the company gained over the existing regulations and the frequent opportunities offered in collaborating to implement new ones. A long-term relationship was established between the company and the explosive inspector which led to benefits for the company since they, to some extent, managed to limit the competition on the market by pointing out inadequacies of other companies and explosives.

Both in 1927 and 1930, the company identified some issues for the inspector that the Nobel company considered of great importance from a safety perspective. The company had received information that some explosives were handled and sold under incorrect forms by another company, and encouraged the inspector to take measures to prevent, not only disloyal commerce, but also obvious infringements of the law. A few weeks later, the inspector contacted the companies in question and ordered the companies to change their method of marketing and selling explosives. He also sent a circular to all County Administrative Boards that aimed to bring an end to such misconceptions. In such cases, the Nobel Company used an indirect method to gain benefits by capturing the staff of the regulator.

Cooperation also developed in a number of safety measurements that later became required by law. In 1926 the Nobel Company managed to get permission to transport 
explosives by truck, even though it had been long since prohibited by law. This was not allowed for other companies. The Nobel Company approached the Inspectorate and suggested that they be given permission to develop a truck, safe enough for road transport of explosives, but that the truck should be approved prior to use and regulated by the Inspectorate. Later on, with the passage of the 1928 Explosives Act, transportation of smaller quantities explosives by truck was permitted, as long as the truck was designed in accordance with the truck Nobel Company had developed. This regulation gave the company a prime position on the market over other companies.

Another example is the development of storage boxes from 1936. Theft from dynamite storages, like stockpiles magazines, was a perennial problem. The Inspectorate of Explosives was requested to help introduce more appropriate depositories. The inspector contacted the Norwegian explosives inspector and obtained a drawing of a storage box used in Norway.

The Nobel Company tested the storage box and leveled much criticism at the Norwegian version. Instead, the company developed a drawing of another storage box, which met higher standards and sent the drawing to the Inspectorate. In 1941, the question of safer depositories was raised again and the Swedish trade minister assembled an expert committee to study the issue. One of the expert commissioners was S. Nauckhoff, managing director at the Nobel Company. In December of the same year, the committee presented a memorandum containing proposals for more stringent technical prescriptions for the storage. In the memo, it was emphasized that the explosives magazines should be storage boxes of a special construction. The description of a "reliable" storage box was very similar to the boxes created by the Nobel Company and the Inspectorate already in 1936. In order to provide such storage boxes on the market, the Inspectorate gave the Nobel Company a requisition to construct and sell the recommended storage boxes. It was possible for other companies to produce storage boxes, but the Inspectorate mentioned that the procedure to get them approved was severe. The high requirements meant high production costs. It was much easier to buy a storage box than to undergo the strict control procedure. The profit from such an investment would furthermore be difficult to recoup when the Nobel Company was already on the market.

In the new regulatory act stipulated in 1948, the Nobel Company, through their collaboration with the explosives inspector, obtained certain privileges over other companies. With their expertise in this area, the company managed to convince the explosives inspector that storage boxes produced by the company were safer than the one the inspector had in mind when the question was raised. This collaboration later led to a decision that storage boxes constructed by the Nobel Company were required by law.

\section{Regulatory Capture and Self-Regulation for the Common Good?}

The traditional Swedish iron works, saw mills and early manufacturing industries often assumed responsibility for the well-being of the workforce and, among other things, provided housing and other facilities for the families, a kind of traditional self-regulation. These were also the services the Nobel Company provided. What distinguished the Nobel Company from other contemporary industries was that they continued to 
work actively to maintain goodwill. Even after they came to dominate the market in the 1900 s, they did this because they cared about the public as third party.

The Nobel Company presented and distributed, for example, its own security brochures with clear instructions for the safest use of dynamite. The safety instructions were printed on the boxes in which the products were packed and transported. In 1909, during an ongoing lockout and forthcoming general strike, the company also took measures to prevent dynamite thefts. The company moved large quantities of dynamite from smaller, unguarded magazines to magazines guarded by the military. They did this to protect the public from dangers that could arise if dynamite was used for criminal purposes.

The company also organized education that aimed at increasing safety for dynamite users. On the initiative of the company, various courses were arranged where dynamite users received training in the handling, storage, and transport of explosives. During the summer of 1932, two courses for rock blasters were, for example, held at the company's factory at Gyttorp. Although the company did not receive any government grants for the courses, and had to subsequently bear all the expenses, the training courses continued annually for many years. The educational efforts might have been a strategy from the company to gain advantage over other companies and through education build up brand loyalty. The kinds of activities described here were not required or regulated by law but were still initiated early and upheld by the company.

\section{Concluding Discussion}

We have argued that the regulation of the Swedish explosives industry up to 1948 can be seen as a process of regulatory capture. With three cases, we discussed various capture processes in the Swedish explosives industry. The two major parties were, on the one hand, the government and its regulatory body and, on the other hand, the Nobel Company. Contrary to other technology and invention-based Swedish industries, the Nobel Company's relationship with the government was manifested through the regulatory process aiming at minimizing the health and safety risks that dynamite and other explosives constituted.

In 1868 the Nobel Company succeeded in convincing the government that liquid nitroglycerin was so dangerous that it should be prohibited and replaced by dynamite, even though the company had held the opposite position the year before. By prohibiting liquid nitroglycerin, the main product for all competing companies, the Nobel Company succeeded in excluding competition from the market as long as the dynamite patent, owned by the Nobel Company, was in force. A nitroglycerin ban would also reduce risks for the public since dynamite was safer to use than liquid nitroglycerin.

The instigation of the Explosives Inspectorate in 1897 was a result of a legislative process that was severely affected by different interests. Before the introduction of the Explosives Act of 1897, a meeting was arranged where protests were primarily made against the fact that the explosives inspector would be given greater influence with the introduction of the Inspectorate the same year. It is thus clear that not all the actors were satisfied with the introduction of a surveillance authority that formalized contact between the parties. Since the Nobel Company did not raise any direct objections 
against the proposal to introduce a government authority, it is likely that they shared the government's view since it would not be as much of a concern for them as for other companies.

Regulatory capture also occurred through indirect methods where the Nobel Company managed to capture the staff at the Explosives Inspectorate. Many of the explosives inspectors had previously worked at the Nobel Company and therefore obtained the bulk of their technical knowledge of dynamite within the company. The long-term relationship between the company and the Inspectorate led to benefits for the company since it, to a certain extent, thereby managed to gain control over the market. Moreover, it also led to the arrangement of activities that benefited the public. The training courses, for example, contributed to reducing the accident rate among dynamite users.

Through the close relationship that evolved between the Nobel Company and the explosives inspector, the company received certain benefits that strengthened the technological upper hand of the company compared as to others. The technological standards the government decided upon stemmed from the experiments initiated by Nobel Company, monitored by the Explosives Inspectorate.

Clearly a form of regulatory consensus developed between the company and the Inspectorate around technical development that gave the company certain privileges over other actors. The traditional industry took up competition with the Nobel Company, but missed the importance of the national market, and up to 1894 fought for the traditional regional authority structure, thus missing the opportunity to go national. This created a golden opportunity for the upstart company to take a leading role in relation to the government and future regulations.

Contrary to most literature on regulatory capture, we emphasize that the outcome of this regulatory capture process lead to advantages for the government, the Nobel Company and the public. The government received the technical knowledge it needed to regulate the industry, a regulation that also reduced risks associated with the manufacturing, transport and handling of dynamite. Although the industry, in this case, the Nobel Company, not only received certain privileges in return for providing the government with the necessary information and knowledge, but could also steer legislation in a direction favorable to the company. Benefits to the public or the common good are not simple and clear-cut concepts and they are often used to disguise the intentions of a certain interest group. With regard to the hazardous explosives industry, we simply refer to the common good as risk minimizing for those in the proximity of the explosives, those living nearby the production sites, workers, users, railway personnel, retailers and storage.

What distinguished the long-term government-company relationship from others in this case was that the company itself stood for the technological development and research. Technological development did not occur in economic or other forms of partnership between the government and the company. Instead, it was long-term regulatory collaboration between the company and the Explosives Inspectorate that distinguished the relationship and may be considered a "regulatory pair."

Open Access This article is distributed under the terms of the Creative Commons Attribution 4.0 International License (http://creativecommons.org/licenses/by/4.0/), which permits unrestricted use, distribution, and reproduction in any medium, provided you give appropriate credit to the original author(s) and the source, provide a link to the Creative Commons license, and indicate if changes were made. 


\section{References}

Andersson-Skog, L., \& Magnusson, L. (2014). Del 1. Samhällsdynamik och industrialisering, pp. 14-197. In M. Larsson (Ed.), Det Svenska Näringslivets Historia 1864-2014. Stockholm: Dialogos Förlag.

Andrén, E. (1964). Nitroglycerin Aktiebolaget 1864-1964. Stockholm: Nordisk rotogravyr.

Becker, G. S. (1983). A Theory of competition among pressure groups for political influence. Quarterly Journal of Economics, 98, 371-400.

Bergquist, A-K. (2007), Guld och Gröna Skogar? Miljöanpassningen av Rönnskärsverken 1960-2000. Umeå studies in economic History, 36, Umeå University, Umeå.

Fridlund, M. (1999). Den gemensamma utvecklingen: Staten, storföretaget och samarbetet kring den svenska elkrafttekniken. Stockholm: Förlag Brutus Östlings bokförlag symposion.

Funke, M. (2015). Regulating a Controversy: Inside Stakeholder Strategies and Regime Transition in the SelfRegulation of Swedish Advertising 1950-1971. Uppsala studies in economic History, 102. Uppsala: Acta Universitatis Upsaliensis.

Hady, D. C. (2006). Regulatory capture in banking. International Monetary Fund.

Latzer, M., Just, N., Saurwein, F., \& Slominski, P. (2003). Regulation remixed: Institutional change through self- and co-regulation in the Mediamatics sector. Communications and Strategies, 50(2), 127-157.

Lundström, R. (1974). Alfred Nobel som internationell företagare: Den nobelska sprängämnesindustrin 1864-1886. Östervåla: Tofters Tryckeri AB.

Peltzman, S. (1976). Toward a more general Theory of regulation. Journal of Law and Economics, 14, 109-148.

Posner, R. (1974). Theories of economic regulation. Bell Journal of Economics and Management Science, 5, 335-358.

Smyth, R., \& Söderberg, M. (2010). Public interests versus regulatory capture in the Swedish electricity market. Journal of Regulatory Economics, 38(3), 292-312.

Stigler, G. (1971). The Theory of economic regulation. The Bell Journal of Economics, 2, 3-21. 